Meta

Journal des traducteurs

Translators' Journal

\title{
Translating the Revolution: Otherness in Cuban Testimonial Literature
}

\section{Raquel de Pedro Ricoy}

Volume 57, numéro 3, septembre 2012

URI : https://id.erudit.org/iderudit/1017081ar

DOI : https://doi.org/10.7202/1017081ar

Aller au sommaire du numéro

\section{Éditeur(s)}

Les Presses de l’Université de Montréal

\section{ISSN}

0026-0452 (imprimé)

1492-1421 (numérique)

Découvrir la revue

\section{Citer cet article}

de Pedro Ricoy, R. (2012). Translating the Revolution: Otherness in Cuban Testimonial Literature. Meta, 57(3), 574-591. https://doi.org/10.7202/1017081ar

\section{Résumé de l'article}

La présente contribution, qui se fonde sur des théories pertinentes du domaine, examine les questions liées à la traduction de témoignages littéraires d'auteurs cubains, sous l'angle de l'inévitable représentation du Soi en tant qu'Autre. La conception de la traduction en tant qu'articulation de l'altérité fait l'objet d'un intérêt croissant en traductologie. Le cadre général de recherche issu de cette tendance n'est certes pas sans mérite ; toutefois la nécessité d'un cadre de recherche spécifique à chaque pays est mise en relief par la position particulière de Cuba sur la scène politique contemporaine - et par l'affirmation de son statut d'" exception » - qui l'a tenue à l'écart des contextes culturels préalablement étudiés. Au vu de cet isolement de Cuba, il convient de mettre en lumière la différence entre la littérature cubaine éditée, traduite et lue en dehors de Cuba d'une part, et la littérature cubaine éditée et lue à Cuba d'autre part. Les résultats d'une recherche menée à la fois sur la bibliographie et sur le terrain indiquent, certes, qu'éditeurs et experts en littérature mettent beaucoup d'emphase sur l'importance de l'altérité. Cependant, il apparaît que leur intérêt se focalise en réalité sur la diffusion de l'expérience cubaine vue " de l'intérieur " (en contrepartie des écrits cubains produits par les auteurs exilés). Dans ce contexte, ils mettent l'accent sur « le caractère universel » de l'expérience humaine et mettent en doute toute altérité qui entraverait le processus de traduction.
Tous droits réservés @ Les Presses de l’Université de Montréal, 2013
Ce document est protégé par la loi sur le droit d'auteur. L'utilisation des services d'Érudit (y compris la reproduction) est assujettie à sa politique d'utilisation que vous pouvez consulter en ligne.

https://apropos.erudit.org/fr/usagers/politique-dutilisation/ 


\title{
Translating the Revolution: Otherness in Cuban Testimonial Literature
}

\author{
RAQUEL DE PEDRO RICOY \\ Heriot-Watt University, Edinburgh, UK \\ r.de_pedro@hw.ac.uk
}

\section{RÉSUMÉ}

La présente contribution, qui se fonde sur des théories pertinentes du domaine, examine les questions liées à la traduction de témoignages littéraires d'auteurs cubains, sous l'angle de l'inévitable représentation du Soi en tant qu'Autre. La conception de la traduction en tant qu'articulation de l'altérité fait l'objet d'un intérêt croissant en traductologie. Le cadre général de recherche issu de cette tendance n'est certes pas sans mérite; toutefois la nécessité d'un cadre de recherche spécifique à chaque pays est mise en relief par la position particulière de Cuba sur la scène politique contemporaine - et par l'affirmation de son statut d'«exception»-qui l'a tenue à l'écart des contextes culturels préalablement étudiés. Au vu de cet isolement de Cuba, il convient de mettre en lumière la différence entre la littérature cubaine éditée, traduite et lue en dehors de Cuba d'une part, et la littérature cubaine éditée et lue à Cuba d'autre part. Les résultats d'une recherche menée à la fois sur la bibliographie et sur le terrain indiquent, certes, qu'éditeurs et experts en littérature mettent beaucoup d'emphase sur l'importance de l'altérité. Cependant, il apparaît que leur intérêt se focalise en réalité sur la diffusion de l'expérience cubaine vue «de l'intérieur» (en contrepartie des écrits cubains produits par les auteurs exilés). Dans ce contexte, ils mettent l'accent sur «le caractère universel» de l'expérience humaine et mettent en doute toute altérité qui entraverait le processus de traduction.

\section{ABSTRACT}

Drawing on existing theories in the field, this paper seeks to explore the issues that surround the translation of Cuban testimonial texts, emphasizing the inevitable portrayal of the Self as an Other. The notion of translation as an articulation of otherness has become a focus of interest in contemporary translation studies. Notwithstanding the worth of the general framework that has emerged as a result, the need for country-specific research is underscored by Cuba's unique location on the contemporary political map - and its alleged "exceptionalism" - which sets it apart from cultural contexts that have been previously studied. Because of the isolated nature of Cuba, it is important to highlight the gap between the Cuban literature that is published, translated and read outside Cuba, on the one hand, and the Cuban literature that is published and read in Cuba, on the other. The results of bibliographical research and fieldwork indicate that, although publishers and literary experts alike place great emphasis on the significance of otherness, their interest centres on the dissemination of the Cuban experience seen "from inside" (so as to counterbalance Cuban narratives produced by exiles). In doing so, they underscore the "universal nature" of the human experience and play down any alterity that may hinder the translation process.

\section{MOTS-CLÉS/KEYWORDS}

Cuba, exceptionnalisme, altérité, révolution, témoignage littéraire

Cuba, exceptionalism, otherness, revolution, testimonial literature 


\section{Background}

Drawing on existing theories in the field, this paper arose from a research project seeking to develop a conceptual framework suited specifically to the translation of Cuban testimonial texts that engaged with the realities of socio-cultural development in Cuba, emphasising the representation of the Self in the source text and its inevitable portrayal as an Other in translation. In addition to this specific focus, it was envisaged that the research would have wider applicability, since it can be generalized to the study of texts originating in non-hegemonic cultures and their translation. This translation project (which is still in progress) will involve the translation into English of post-Revolution testimonial short stories by Onelio Jorge Cardoso (19141986), Manuel Cofiño López (1936-1987), María Elena Llana (born 1936), Eduardo Heras León (born 1940), Julio Travieso (born 1940), Mercedes Santos Moray (born 1944), Mirta Yáñez (born 1947), Francisco López Sacha (born 1950), Marilyn Bobes (born 1955) and Aida Bahr (born 1958). These stories have not been previously translated into English and they provide a snapshot of narrative produced in Cuba since the Revolution. ${ }^{1}$ Given the lack of access to representations of post-1959 Cuba outside the island, a selection of Cuban short stories from the five decades of Revolution to be translated for publication will offer fictional (literary) narratives reflecting a wide range of experiences throughout the revolutionary period.

Thanks to a grant from the Carnegie Trust, I was able to visit three libraries, attached respectively to the Casa de las Américas, the Instituto de Literatura $y$ Lingüistica and the Facultad de Artes y Letras in Havana. The bibliographical research I conducted enabled me to access journals that are not readily available outside Cuba and to gain an understanding of the historical evolution (early 1960s-2000s) of the paradigms for "understanding" Cuba, both within the country and overseas (from the prevalence of the premises of Cuban exiles in the two decades following the Revolution to the boom in less biased socio-cultural studies which started in the 1980s). I was also able to look at academic papers specifically analyzing the development of Cuban story-telling and I found that there is substantial contemporary theorization as to translation within Cuba which is little known elsewhere.

I also conducted interviews with two editors working for major publishing houses, José Quesada Pantoja (Publishing Editor, Pueblo y Educación) and Victor Malagón (Chief Specialist, Arte y Cultura), who provided me with very useful insights into publishing policy in Cuba. I also interviewed Daniel García (Director, Instituto Cubano del Libro), with whom I discussed the selection of authors for the project and who gave me three anthologies and one contemporary collection of Cuban short stories, so that I could have an overview of the types of narrative that are deemed worthy of publication in Cuba. ${ }^{2}$ At the Instituto de Literatura y Lingüistica, I met with Gisela Cárdenas Molina (who is the President of the Asociación de Lingüistas de Cuba and the Secretary of the Academia Cubana de la Lengua) and its Chief Researcher in Cuban Literature, Emmanuel Tornés (writer, literary critic and university professor). Our discussions, during which their experience and knowledge was of invaluable help, revolved around the thematic and narratological evolution of Cuban tales from the triumph of the Revolution onwards.

All the interviewees expressed their support for the translation project and emphasized the importance of disseminating works by authors (some of whom belong 
to the Cuban literary canon) who are virtually unknown abroad, as a way of counterbalancing the notions regarding "the Cuban experience" that are derived from the translations of exiles' narratives.

Additionally, I held two meetings with colleagues from the Facultad de Lenguas Extranjeras (FLEX) of the Universidad de La Habana and led four translation workshops in collaboration with them. These afforded me the opportunity to exchange opinions with academics, postgraduate students and professional translators on issues pertaining to the project, such as the semiotic dimension of translation, intertextuality and perceptions of genre and discourse.

\section{Introduction}

In his comprehensive overview of scholarly approaches to Cuba, Kapcia claims that "all research disciplines must come to terms with aspects of the Cuban reality that do not easily fit paradigms" (Kapcia 2008: 649). Literary studies are no exception: the dichotomy between the works of post-Revolution Cuban exiles and those of writers who are based in Cuba is rarely tackled from an academic perspective. Whereas many of the members of what has become known as la diáspora cubana, from Cabrera Infante (1929-2005) to Zoe Valdés (born 1959), have published their works to great international acclaim and have even made the transition to other media, such as cinema, successfully, Cuban authors who reside in their homeland are virtually unknown elsewhere. This can be partly attributed to the apparent lack of interest on the part of foreign publishing houses to disseminate their work in Spanish and, crucially, in translation.

On the other hand, literary translation within Cuba has traditionally been prolific. ${ }^{3}$ One of the five associations that make up the Cuban Union of Writers and Artists (Unión de Escritores and Artistas de Cuba, UNEAC), the Asociación de Escritores, actively engages with translation projects and provides a forum for the discussion and dissemination of issues that pertain to literary translation (ranging from its history to copyright and other legal concerns). Similarly, Casa de las Américas has promoted the publication in Spanish of works by Caribbean authors who write in English or French, as well as those of Brazilian writers. The site cubaliteraria.com devotes one of its pages (Traduttore/Traditore) to reflections by leading Cuban intellectuals on translation-related matters. The dissemination of foreign literary production is further encouraged by translation awards, such as the Premio José Rodríguez Feo for literary translation. However, translation from Spanish into other languages is dispreferred.

In stark contrast with this trend, publishing experts in Cuba, such as José Quesada Pantoja (2008 - see the Interviews section) and Victor Malagón (2008), as well as Daniel García (2008), emphasize the importance of spreading works by authors (some of whom belong to the Cuban literary canon) who are unknown abroad, as a way of counterbalancing the notions regarding "the Cuban experience" that are derived from the translations of exiles' narratives. Thus, it is important to highlight the gap between the Cuban literature that is published, translated and read outside Cuba, on the one hand, and the Cuban literature that is published and read in Cuba, on the other. As indicated above, although studies on the former are substantial, a theoretical approach to the translation of the latter is an original line of research. 
The most popular "autochthonous" genre in Cuban literature is the short story, especially in the form of testimonial literature. Due to the relative isolation of Cuba which ensued as a result of the triumph of the Revolution in 1959 and was accentuated by the collapse of Communism in 1989, as well as because of domestic political and social factors, the siting of this type of literature in a wider tradition of translated fiction is of particular interest. Arguably, what differentiates the narratives produced in Cuba from those by Cuban writers who reside abroad is the immediacy of the experience that is recounted, undoubtedly tinged by national ideology and subjected to constraints. The key is that, whereas Cuban exiles evoke, often with nostalgia, sometimes with bitterness and always critically, a reality of which they are no a longer part, the authors based in Cuba tell their readers about a context which is very much their own and which, more often than not, they share with them. Thus, the former communicate with a wider and more varied audience, who frequently have preconceptions about a country they have never visited or of which they have the necessarily limited experience afforded to visitors. The latter, on the other hand, can establish a more complicit relationship with their readership (which is not to say that they do not seek to challenge them), based on recognition and familiarity. Exoticism versus propinquity, alterity versus commonality becomes, therefore, the basic distinction from the point of view of the reading experience. The literary production of exiles is located in foreign polysystems, which have their rules and norms as to what gets published and how, based on cultural preferences and commercial considerations. In the same way, both aesthetic criteria and market forces determine what gets translated and into what languages. The dissemination of the works by Cubabased writers is also affected by institutional and pragmatic ${ }^{4}$ constraints, but, as stated above, it generally only happens through the medium of the Spanish language.

The question arises, then, of how best to tackle the translation of Cuban testimonial works, of how the construction of meaning can be facilitated via translation when the subject is an "Other" that does not easily fit into established paradigms. In fact, as Kapcia remarks, drawing on Hoffmann and Whitehead (2007), "The case for 'exceptionalism' in the study of Cuba [...] has been stimulated by the contradiction between Cuba's seemingly inexorable movement towards transition and the continuing evidence of the system stubbornly bucking the trend" (Kapcia 2008: 627).

The notion of translation as an articulation of otherness has become a focus of interest in contemporary translation studies. The application of this concept and that of "de-centring" to modern translation theor $y^{5}$ is derived from sociological discourse. Even though these concepts are usually associated with post-modernity and globalization in the late twentieth century, they have been formally addressed in terms of social theory and human sciences since the mid-nineteenth century: it can be argued that Marxist thinking (which was revisited in the 1960s) is the first major de-centring effort of the Cartesian conception of identity derived from the Enlightenment. Notwithstanding the worth of the general framework that has emerged as a result, the need for country-specific research is underscored by Cuba's unique location on the contemporary political map, which sets it apart from cultural contexts that have been previously studied. This is not to say that the contribution of scholars working in the fields of translation (e.g., Even-Zohar 1979; Toury 1980; 1995), philosophy (e.g. Benjamin 1923/1992; Derrida 1981) and post-colonial studies (e.g., Niranjana 1992; Bhabha 1990; 1994) should be disregarded; rather, that their tenets need to be 
contrasted with the idiosyncrasies of Cuban reality. Indeed, it can be argued that, because of the prioritization of the Cultural Revolution, the questions revolving around marginality and otherness in Cuban testimonial literature may be appropriate for many post-colonial contexts.

Let us now outline some of the theoretical principles that have informed the debate regarding the portrayal of otherness in translation.

\section{Otherness and literary translation}

Keeping a balance between sensitivity towards the source text and a commitment to the target text, between what Hatim and Mason call "Author-centred and Readercentred Translating" (Hatim and Mason 1990: 16-19), means that translators have to reconcile the foreignness, the otherness, of the source text, on the one hand, and the orientation of the target text towards a potential readership which belongs to a different cultural context, on the other. This predicament may be interpreted as a regression to the age-old debate between "fidelity" to the original and the comprehensibility and naturalness of the translation (whether desirable or not), but, as the developments in translation theory which took place in the second half of the twentieth century illustrate, it is far more complex than that.

The type of discourse and the genre of the text involved are important considerations when deciding which orientation should be given to the translation. Linked to this issue are the readers' approach to the target text and their expectations. Interlingual translation does not only involve a linguistic transfer, but also a transfer from the source culture to the target culture. How is otherness instantiated in the source text? It could be thematically, although one could argue that this is a question of cultural transfer that does not affect only translation (the otherness of a Cuban text can affect readers whose mother tongue is Spanish but are natives of other countries as much as those readers who access it in a different language). If the focus is placed on linguistic features, otherness can manifest itself in the formal characteristics of a genre or sub-genre, and also, at a more localized level, in culture-bound ${ }^{6}$ textual elements which are vehicles of signification pertaining to specific geographical and/or chronological contexts. These elements may fall into one of three broad categories:

a) Culture-specific terms or concepts, i.e., terms or concepts which belong specifically to a given cultural context and are therefore alien to other cultural contexts (or, at least to the target cultural context in each case);

b) Terms or concepts which are not necessarily specific to the source culture, but have been introduced in it and have become assimilated;

c) Terms or concepts which present connotations specific to the source culture, although they are not specific to it in themselves.

The translator is, as ever, faced with a choice. Should the culture of origin be "de-centred," and the Other displaced towards the target culture? Or should the readers of the target text "de-centre" themselves, and move towards the Other? Translation is always a portrayal of the Other, as expressed in the source text, interpreted and mediated by the translator. Therefore, the expression in the target texts of the components that signal this otherness is bound to be coloured by the translator's perception and ideological bias. Even when the translator's choice is to reflect 
the otherness of the text by maintaining the links that culturally-marked elements establish with the source culture, the options available cannot always help attain that goal. It seems beyond all doubt that certain discrete textual elements pose translation difficulties, not only by virtue of their linguistic nature or configuration, but also by virtue of their relationship with the source culture. However, further complications arise when we move to the textual and supra-textual levels (e.g. how the construction of humor or identity is effected in a short story).

A translation that maintains the differences between the source and the target cultures can make the readers of the target text more aware of cultural features and idiosyncrasies. Cultural differences, nonetheless, can (and often do) make the target text obscure or lead to losses in signification. The translator, as a communicator and a cultural mediator, is confronted with a dual task: to preserve the foreignness of a text and, at the same time, to produce a target text which is coherent and comprehensible. A very fine balance between two objectives should be considered:

a) Keeping the source text in its own context, and, in so doing, facilitating the acquisition of information on a different culture by the readers of the target text;

b) Facilitating the understanding of a foreign product for those who do not possess the knowledge of the source culture which is required to apprehend the meaning of the original text.

Elements which are culturally-marked may pose translation difficulties essentially for two reasons:

a) Because they are likely to be interpreted in a different way in the target culture. These can exist in both the source and the target cultures or be foreign, but wellknown, in the source culture. Precisely because they may not be perceived as alien to the target culture, their true significance within the source culture, which is different, may be overlooked in translation. However, it is worth noting that their connotative meaning can sometimes be inferred from the context;

b) Because they are unknown in the target culture. These could be culture-specific elements proper or elements which derive from other cultures but have become common currency in the source culture. The clarification of these terms is comparatively simple: it can be done by means of an explanatory addendum to the source text, or by substitution of an element which is understandable in the target text for the original one. However, this could involve a loss of information about the source culture in translation.

Therefore, translation issues derived from the occurrence of culture-bound elements in the source text can be of two different types:

a) They may arise from the different perception of a given element in either cultural frame;

b) They may arise from the non-existence of a given element in the target culture.

In the first case, the difficulty in the transfer is fundamentally rooted in culture, since the substitution of lexical elements, if required, is straightforward. The second instance, however, additionally involves a linguistic dimension, since no straightforward substitution is possible at the lexical level, although a number of strategies are available in such cases.

It can be argued that the translatability issues which arise from manifestations of otherness lie with extra-textual circumstances (i.e., the background and expectations 
of the readers), rather than with specific textual elements per se, which can be transferred in different ways. Furthermore, contextual information is usually a valuable aid in minimizing comprehension problems: the "difficult" element may be accompanied by qualifying or defining descriptive items within the source text itself. In spite of this, culturally-marked elements in the source text tend to be more easily accessible to those familiar with the source culture and may, therefore, alienate the readers of the target text, especially if the source text is rich with elements which are foreign to these readers. ${ }^{7}$ The perception of elements which are bound, in one way or another, to the source culture may be distorted by their cultural experience or expectations. In some cases, their understanding of the text may be impaired by the appearance of elements unknown to them, unless the translator opts for producing a target-culture oriented text. On the other hand, the presence of culture-bound elements in the source text has the positive quality of conveying information about the source culture: it brings readers closer to the cultural Other.

Granted all of the above, it has to be borne in mind that the representation of the otherness of a literary text in a foreign language hinges on factors that go beyond the difficulties that the appearance of culture-specific terms and expressions may entail. An awareness of the ideological dimension which translation unavoidably involves is desirable, as there are many ways of engaging with (or manipulating) a source text. The main concern is how scholars and practitioners exploit the notion of the Other in a text with regard to translation, where, as Berman says: "The native strangeness of the work is joined by its strangeness (effectively increased) in the foreign language" (Berman 1992: 127). Yet some translators may choose to erode this strangeness in order to present their readers with naturalness of expression and/or to enhance comprehensibility, and, as a result, denunciations of suppression and repression of the Other have been rife in recent times.

Venuti (1995) shows how translation can control otherness both from an aesthetic and a cultural point of view. His evidence appears to contradict the widespread notion of what, ideally, translation should be: "The essence of translation is to be an opening, a dialogue, a cross-breeding, a decentering. Translation is a 'putting in touch with' or it is nothing" (Berman 1992: 4). The reason for the divergence between what a translation should be, according to entrenched prescriptive approaches, and what it often becomes in actual fact lies in the resistance to translation, which, it has been argued, characterizes all societies:

Every culture resists translation, even if it has an essential need for it. The very aim of translation - to open up in writing a certain relation with the Other, to fertilize what is One's own through the mediation of what is Foreign - is diametrically opposed to the ethnocentric structure of every culture, that species of narcissism by which every society wants to be a pure and unadulterated Whole. There is a tinge of the violence of cross-breeding in translation. (Berman 1992: 4)

Berman refers to cross-breeding as "violent," but it could well be (and it often is) a voluntary act, one that is conducive to an enrichment of both the Self and the Other, one that results in a whole that is larger than the sum of its parts. Nonetheless, terms such as "violence" and "aggression" are not uncommon amongst critics working in the field of post-colonialism and gender studies who point to the existence of power relations that are inherent in the act of translation from one culture to another. Venuti (1995: 20) discusses "the ethnocentric violence of translation" and argues that "inso- 
far as foreignizing translation seeks to restrain [this violence], it is highly desirable today, a strategic cultural intervention in the current state of world affairs." ${ }^{\text {A }}$ Although he refers specifically to the cultural imperialism of English-speaking countries (he mentions "the hegemonic English-language nations and the unequal cultural exchanges in which they engage their global others"), foreignizing translation is a strategy applicable to any given pair of languages.

Others have also drawn attention to the perils of a naturalizing translation. Niranjana, for instance, accuses Translation Studies of ignoring "not just the power relations informing translation but also the historicity or effective history of translated texts" (Niranjana 1992: 59). Nevertheless, Bassnett and Lefevere tend to suggest a greater awareness of the issue than Niranjana's words imply:

Translation is, of course, a rewriting of an original text. All rewritings, whatever their intention, reflect a certain ideology and a poetics and as such manipulate literature to function in a given society in a given way. Rewriting is manipulation, undertaken in the service of power, and in its positive aspect can help in the evolution of a literature and a society. Rewritings can introduce new concepts, new genres, new devices, and the history of translation is the history also of literary innovation, of the shaping power of one culture upon another. But rewriting can also repress innovation, distort and contain, and in an age of increasing manipulation of all kinds, the study of the manipulative processes of literature as exemplified by translation can help us towards a greater awareness of the world in which we live. (Bassnett and Lefevere 1992: vii)

When considering the dichotomy between foreignizing and naturalizing translation strategies, it is worth considering that, indeed, otherness can be, and often is, alluring. Nevertheless, making alterity marketable (or, indeed, palatable) in the framework of a hegemonic cultural system can lead to the deployment of translation strategies that make the target text conform to alien perceptions and expectations. This is another factor that helps understand why some critics understand translation in terms of a power relation:

The writings of Rafael, Bhabha, Niranjana and Cheyfitz in particular seek to articulate 'translation' as a central problematic in the analysis of ethnic and cultural transfers, refusing the traditional Enlightenment position of understanding the 'Other' but trying instead to think through what Cheyfitz terms 'the difficult politics of translation, rather than the politics of translation that represses this difficult politics.' (Evans 1998: 149)

It is important to point out that post-colonial scholars working in the field of social anthropology tend to use the term "translation" in its etymological sense (i.e., translocating, or effecting a change of locale). Simon articulates the reason why Bhabha's notion of translation differs from the most commonly accepted meaning of the concept in the following terms: "Translation is not a mechanism of transfer or a naturalization of meaning, because the extremes of Otherness have collapsed into the ever-growing center between them" (Simon 1996: 153).

Indeed, Bhabha's approach differs from that of scholars like Even-Zohar or Toury, who also take power relations between cultures as a starting point. It is, however, closer to the "cultural turn" that took place in Translation Studies in the 1990s ("we translate cultures"). Bhabha does not deal with translations and their role in a given cultural system per se, but rather with the articulation of cultures in other languages. This is possible because a feature that all cultures have in common is that they are "symbol forming and subject-constituting, interpellative practices" (Bhabha 1990: 
209-210), despite the essential differences between them: cultural values and priorities are characterized by their "incommensurability" (Bhabha 1994: 173). For Bhabha, it is displacement (for he defines culture as being translational, as well as transnational [see Bhabha 1994: 172]) that "opens up the possibility of articulating different, even incommensurable, cultural practices and priorities" (Bhabha 1990: 210-211). He claims that the processes of displacement and transformation within and across cultures produce "the third space" (see Bhabha 1990), which Evans defines as:

an identification, rather than an identity, where there can never be a full translation of subjects or of forms of culture, but which is hybrid and which bears, like a translation, traces of former meanings that give rise to new areas of negotiation of meaning and representation, but never in an essentialized form. (Evans 1998: 152)

The concept of culture as a symbolic (signifying) activity derives from Benjamin's essay The Task of the Translator (first published in 1923), upon which deconstructionists drew in order to articulate a different dimension in the relationship between source and target texts. In deconstructionist terms, the debate is no longer restricted to whether naturalizing translation is a "betrayal" of the Other. Instead, for the deconstructionists, source-text oriented translation strategies lead to a surrender to the Other:

This concept [Nachträlichkeit, i.e., 'post-humous-ness'] can [...] be seen as a motivation for ideologically interfering with the original, on the grounds that new richness is being added to the work: if original meaning does not exist and if the work lives on in the endlessly deferred meaning of the play of the signifier, then various forms of adaptation become justified as the main translation technique. Gender politics lead to the same conclusion. In these circumstances, translation becomes not a submission to otherness, but a performance art with procedures exactly comparable to those used in modern-day stagings of classical theatre and opera. (Robinson 1998: 107)

Thus, the limits of what used to be conventionally understood as translation are expanded: it is no longer a transmission of the original meaning (since, according to deconstructionist tenets, there is no such thing), nor of forms (which are no longer perceived as being the carriers of a meaning that does not exist). It becomes a boundless activity in which translators are no longer re-creators, but creators in their own right.

As Robinson's analysis above indicates, this approach has also influenced feminist translators. ${ }^{9}$ Controversial though these intellectual and ideological stances may be, it can be argued that the contribution of scholars working in the field of postcolonial and gender studies has had great relevance with regard to translation theory: not only do they place otherness in a wider ideological context than that provided by more traditional theories, they also draw attention to the fact that translation, in one way or another, is a portrayal of the Other that has to be considered in the light of power relations between languages, cultures and groups.

The next section attempts to link these concepts to the translation of Cuban testimonial literature. 


\section{Translating the Revolution: Findings}

It should noted that the views of individuals quoted in this section are their own, as recorded in interviews. All were interviewed in the context of this translation project, but none of them is, or claims to be, a translation specialist or scholar. Nevertheless, they all have views on translation that stem from their professional experience and are especially pertinent in the context of this study. The opinions and stances of authors and translators, which will inevitably stem from concerns that differ from those of literary and publishing experts, are not incorporated into this stage of the study, as they merit separate consideration and analysis.

From the point of view of genre, sub-genre and discourse, it can be argued that the short story and testimonial literature are well established in western literary systems, which means that the translation of this type of Cuban texts would not have the "destabilizing" effect that is one of the main concerns within (poly)systemic approaches in this respect.

As for culture-bound lexical elements, their presence in the source texts raises the question of how to reproduce them in the target texts, how to make them understandable to a foreign audience. As stated above, the scope of the difficulties that may arise is arguably limited, since a number of strategies (ranging from the naturalizing to the foreignizing) are available to the translator in order to achieve this aim. Taking two short stories as examples (Llana's Un abanico chino and Yáñez's Todos los negros tomamos café), reference will be now made to the translation issues mentioned in the previous section with regard to these textual elements.

It was mentioned that certain lexical elements do not ostensibly pose translation difficulties, because they may not be perceived as alien to the target culture. For instance, the term brigade (which derives from the French brigade) is as widely used in English as brigada is in Spanish. However, when Yáñez (1976/2003: 158) mentions the brigadistas, she is referring specifically to the people who support the Revolution by conducting volunteer work, a semantic property which is absent from the English term. The meaning can, in this case as in many others, be constructed from cotextual references, but it would not work in itself as a vehicle for the transmission of meaning in English.

Other lexical items denote entities unknown in the target culture, either because they are specific to the source culture or because, although they derive from other cultures, have become assimilated in the source culture. An example of this is the comparseros in Llana (1983/2003: 152), who are the members of groups who coordinate their attires to parade on the streets during carnivals and other celebrations in Spanish-speaking countries. The clarification of such terms is comparatively simple: it can be done by means of an explanatory addendum to the source text, or by substitution of an element which is understandable in the target text (such as a hypernym) for the original one. These strategies are also often applied to proverbs and idioms. Yáñez makes one of her characters reflect on how spoiled she was as a child by using an abbreviated form of a saying: Si pajarito volando pedía, pajarito volando $^{10}$ (Yáñez 1976/2003: 158). Later on, the same character remarks, Que el que no tiene de congo (Yáñez 1976/2003: 159), a shortened version of the Cuban proverb "El que no tiene de congo tiene de carabalí," are racially mixed in one way or another. It has to be borne in mind, though, that 
particularly in cases such as the latter of the two mentioned here, translation by substitution would involve a loss of information about the source culture, as it would entail a decontextualization of the Cuban proverb and its lexical components.

However, as mentioned in the previous section, it is in extra-textual factors, such as the readers' background and expectations, where the effective transfer of meaning may reside. Given that, inevitably, translation involves a displacement of the source text and its recoding in an alien cultural framework, it is unavoidable that such factors will be altered.

Llana's story provides an insight into the social and moral decline of the preRevolution bourgeoisie which is very much tied into Cuba's political history. The very title of the collection in which it appears (Casas del Vedado) evokes vestiges of a time gone-by at the time of its of publication, when El Vedado was the preserve of the wealthy in Havana. The core of the story is anchored in the past, in an era when the protagonist family enjoyed social and economic clout. In the narrative present, their existence is confined to the shadows, which are demarcated from the light by the house's fence: "La iluminación del sol comenzaba en el pedazo de acera que se veía frente a la entrada de la verja, como si allí mismo se estableciera el límite entre la luz y la sombra"12 (Llana 1983/2003: 152). The concluding part of the story reveals how the misdemeanours of the past are repeated and amplified in the present, in an illustration of what Cardentey Levin calls

[...] the gradual decay of the petite bourgeoisie, and, more specifically, of those of its members who chose to shut themselves down in their living spaces by way of response to the deep-reaching transformations in the political and socio-economic infrastructure that the Revolution brought along. ${ }^{13}$ (Cardentey Levin 2009; my translation)

Similarly, Todos los negros tomamos café has, from the outset an inextricable link to the island. Its title (which it shares with that of the collection of short stories of which it is part) is a line in a popular Cuban song, Mama Inés. When translated into English, the intertextual link is broken and, as a result, its status as a vehicle of signification disappears: Mama Inés is believed to have been one of the African slaves who were brought into the island to work in the coffee plantations and the line "todos los negros tomamos café" is used nowadays to signify equality. It anticipates the focus of the story: the clash between the value systems of the two characters. The post-Revolution order is represented by the daughter, who wants to join volunteer workers (the aforementioned brigadistas) to help harvest coffee in the mountains and whose stance does not seem marred by social or ethnically-related prejudices. The status quo is embodied by the mother, who is terrified of the shame that would befall the family should her daughter pursue her plan, especially if she were to become pregnant by a black man, as "una niña blanca debía ser cuidada al máximo"14 (Yáñez 1976/2003: 159).

It seems unavoidable that the displacement of the stories will result in some loss in meaning. It can be argued that this is the case with any literary text, but issues relating to readers' expectations and the translator's ideology are especially relevant in the case of Cuban testimonial narratives, given the "exceptional" nature of the Cuban experience. For this reason, it is interesting to note that publishing experts, policy-makers and academics alike highlight in various terms the importance of translation as displacement (in the sense intended by Bhabha) and yet, at the same time, underscore the need of a transfer which, albeit open to negotiation for the construction of meaning to be feasible, stays close to Cuban reality as seen from 
inside. In a departure from "exceptionalist" approaches to Cuban literature, all interviewees seemed to concur that this would not constitute a hurdle in terms of translation, given the universality of the themes that are dealt with in Cuban testimonial literature. Tornés (2008) referred explicitly to the "universal character of the human experience"15 which is reflected in post-Revolution Cuban narrative.

Quesada Pantoja (2008) emphasized the importance not only of being familiar with Cuban reality in order to be able to understand it ("in order to understand what happens in Cuba, one has to live in Cuba"), ${ }^{16}$ but also of empathizing with it in order to transfer it to a different context: the translator would need to have been involved in all the situations that characterize the Cuban experience. ${ }^{17}$ Yet, when asked about the inevitable losses that occur in translation, stated that the greatest shame would be that foreign-language readers did not become aware of what is really happening in Cuba. ${ }^{18}$ This is indicative of a seemingly overwhelming preoccupation with content over form. Of all the interviewees, Tornés (a writer, literary critic and university professor) was the only one who remarked on the need for the translator to show extreme sensitivity to formal aspects. He stressed the concomitance of form and style in the narrative of some authors by quoting the importance of the "mental syntax"19 in the work of Cardoso and said that the translator ought to be a "good reader" 20 in order to capture the linguistic structure of the stories. As well as being able to translate (in the etymological sense) the essence and the atmosphere of the story, ${ }^{21}$ the translator has to interpret the literary work in such a way that foreign-language structures reflect the dynamics of Cuban Spanish, so that "the flavour of all things Cuban" 22 pervades the narrative. He concluded that: "The subject matter is the skin, but the most important thing in translation is the soul, the nervous system." ${ }^{23}$ Thus, he highlighted the role of the translator as a literary creator and not a mere scribe.

All experts consulted agreed that the displacement of the foreign reader towards the Cuban experience was paramount, in an apparent rejection of domesticating or naturalizing strategies, along the lines of the strategy advocated by Venuti in order to resist cultural imperialism. The interest for foreign readers would reside in Cuba's reality, as Quesada Pantoja put it, and they need to "draw themselves towards Cuba" 24 in order to understand the texts. When asked about how foreign readers would approach this "Cuban reality" from very different cultural contexts, there was some agreement that there would be an element of surprise in their journey of discovery: Quesada Pantoja stated that "the experiences that are recounted and the way in which narration is constructed" 25 may be a revelation. However, in an acknowledgement of the developments of a cultural system that is often seen as stagnant from abroad, the interviewees emphasized that there has been a significant evolution of themes and styles from the early days of the Revolution onwards. Quesada Pantoja stressed the emergence of new forms of storytelling and the parallel with other countries all over the world. ${ }^{26} \mathrm{He}$ reflected on the fact that the contradictions, or contrasts, between the new generations and the ones that preceded them are rooted in new ways of thinking, of approaching life and of facing up to problems. ${ }^{27}$ Tornés dwelled on the loss of innocence ${ }^{28}$ in the 1990s, which resulted in the emergence of new themes and new approaches to issues that have to be dealt with on a daily basis, while stating the importance of historical memory and the revival of those writers from years gone by who deserve recognition. ${ }^{29} \mathrm{He}$ also underscored the relevance of female writers who reacted against masculinist norms (a reaction that, as mentioned above, has been 
studied by scholars in the West; see Simon 1996), notably, María Elena Llana, who felt "suffocated" 30 by such norms. García (2008) spoke of a very significant change, ${ }^{31}$ both thematically and stylistically, from the narrative of the early 1960 s to contemporary storytelling and insisted on the importance of getting to know the work of the younger generations of authors who are still not part of the Cuban literary canon (e.g. Miguel Collazo, Rafael de Águila, Ana Lucía Portela and Ana Lydia Vega), because of their aesthetic and thematic contribution.

In relation to the above, all interviewees commented on the difference between Cuban narratives produced outside Cuba and the autochthonous literature. Quesada Pantoja acknowledged that "usually, the ones whose work is published in other languages are dissidents, people who do not live in Cuba, the diaspora." ${ }^{32}$ There was broad consensus as to the fact that exiles have access to broader distribution channels and, also, as to their approach to Cuban reality: as García put it, "their starting point is a different reality"; 33 and their "sense of "Cubanness" 34 is framed by a different context; however, their success in foreign environments was attributed to different reasons. Tornés denied that their production is necessarily closer to mainstream western aesthetics and cultural preferences "necessarily, because they are Cuban [...] they are always looking to Cuba," 35 attributing their popularity to the fact that their literature is the product of them "being immersed in varied sources of information," 36 thus being "more in tune with international reading preferences" 37 by dint of their daily contact with other cultures, traces of which are noticeable in their writings. ${ }^{38}$ Nevertheless, he alludes first and foremost to "extraliterary reasons" 39 , a view that is reiterated by Quesada Pantoja: "there is a lot of propaganda and a lot of money backing up accounts of the Cuban Revolution seen from the outside." ${ }^{\prime 4} \mathrm{He}$ added that the "difficulty lies in talking about what is happening in Cuba from the inside" you want to reach a wider audience.

In terms of the status of home-grown literary production with respect to imports (and vice versa), an issue that has been extensively studied in the context of polysystemic approaches to translation, Quesada Pantoja (2008) and Malagón (2008) stated that there is not necessarily a distinction as far as the readership is concerned, although this is a very complex issue, as Malagón remarked. There was an acknowledgement of the fact that the market for literary translation in Cuban publishing houses is more limited than in other countries, ${ }^{42}$ but Malagón underscored the primacy of quality, ${ }^{43}$ of the "spiritual value" 44 of literary work against sales potential when making decisions as to what to translate, quoting Cuban translations of the works of Umberto Eco and H.P. Lovecraft as examples of modern classics that have found their place alongside the translated works of canonical authors, which are, according to Quesada Pantoja, by far, the most popular. ${ }^{45} \mathrm{He}$ also acknowledged that, as in any other country, it is difficult for newcomers to get published. ${ }^{46}$ and that there is a marked difference in terms of distribution and, therefore, popularity, between the works published in Havana and those that are published in the provinces. Institutional factors are also important: Quesada Pantoja mentioned "self-censorship in publishing houses" ${ }^{\text {"7 }}$ lest the ideas expressed by the authors could be "misinterpreted" 48 or "misunderstood by the readership." 49 This alleged "self-censorship" is, of course, both problematic in terms of the reader's role in constructing meaning and crucial in terms of the dissemination of Cuban literature abroad, as the works that can be translated are, as a rule, the ones that have been published. 
One thing that all interviewees were in agreement about was the importance of establishing a different perspective in relation to Cuban reality as perceived through literary works in translation, so as to counterbalance the views and values portrayed by exile writers that have coloured the expectations and informed the views of foreign readers. ${ }^{50}$ Quesada Pantoja put it in terms of a national commitment, "to engage Cuba with those writers, so that they can become well-known." ${ }^{11}$ The achievement of this objective is, necessarily, contingent on external factors, however: publishing policy in Cuba and market forces in the West are contentious issues that deserve careful consideration.

\section{Conclusion}

The "exceptionalist" stance on Cuba and the tension between national and foreign paradigms makes the translation of testimonial texts produced within Cuba an extremely interesting subject for research.

It is not surprising that, when presented with the possibility of the dissemination of autochthonous texts beyond the borders of their homeland, the consensus amongst Cubans involved in the publishing industry (which is, incidentally, shared by academics) is that it is highly desirable. The general agreement is that translation should focus on content, on a reflection of Cuban issues as seen from inside. Although some concerns are put forth regarding the formal and stylistic features of Cuban texts in the relation to their relevance in translation, the overwhelming sentiment seems to be that the universal character of the human experience reflected in post-Revolution texts makes them ideal subjects for translation.

This can be attributed to the desire of all communities for representation and recognition, but in the case of Cuba it is enhanced by the wish to counteract the representations of the country that, because of historical, social and economic reasons, are prevalent in a world context which, perhaps paradoxically, has very close links to Cuba for the very same reasons. According to those interviewed, the Cuba that is portrayed in the writings of exiles has little to do with the Cuba that is written about from within, both in terms of thematic and stylistic preoccupations. This is, of course, contentious, as literary representations which may be critical of the regime or the values of the Revolution would not be published, and does not necessarily imply that a different paradigm should be applied when it comes to the translation of works by exiles and non-exiles. Nevertheless, one should not lose sight of the fact that, when writing about Cuba, the former operate within environments (or polysystems) which are subject to norms and conventions that differ substantially from those that apply to the literary creation of Cuban residents. Within Cuba, the emphasis seems to be on translating (or transferring) a cultural experience that has been, so far, unrepresented. Foreignization is a valid strategy inasmuch it brings readers closer to understanding the reality of Cuba without impeding their comprehension thereof. A tall order, by any translation standards.

Whereas Tornés ventured that the post-Revolution authors that had been selected for this project would not be too difficult to translate from a formal point of view (he stated that, unlike some other Cuban writers, "they are not authors with a baroque bias" 52 and exercise restraint in their use of language," ${ }^{33}$ others remarked on the difficulty of making the Cuban experience truly accessible in a foreign language. 
Quesada Pantoja, for instance, observed that it may be problematic to translate texts (or passages of texts) that are "deeply embedded in Cuban everyday life," ${ }^{4}$ as it would be extremely difficult to uproot them "in order to transfer them to a different place." 55 (He suggested compensatory mechanisms, such as "notes, explanations for the reader or a glossary." ${ }^{56}$ ) However, this kind of compensation would probably restrict the diffusion of texts that are perceived as crucial to the Cuban experience to a broad audience. After all, critical editions of literary works target a limited readership of people who access them for very specific purposes. This seems to be in contradiction with the eagerness to counterbalance the impact of exile literature in translation.

In relation to the above, institutional constraints, both in Cuba and elsewhere, make the dissemination of autochthonous Cuban texts difficult. It can be argued that what is published in Cuba is not necessarily marketable in other countries, due to considerations that have to do with legal frameworks (e.g. copyright across different economic systems is, in itself, problematic) and market forces, which determine what is published and translated.

To sum up, although the dissemination of autochthonous Cuban texts in foreign languages is desirable, so as to open a window into a reality that is alien to their potential readership, the task is difficult to conceptualize in terms of the existing translation theory. It can be argued that the main task that a translator has to face is that of bringing cultures closer to each other. The closer translators stay to the source text, the more their readers will learn about the foreign culture. As a rule, the further they depart from the original that they are translating, the more easily understandable the target text will be in the target culture. A foreignizing translation would be less "imperialistic" than a naturalizing translation and it would be less transgressive of source culture and source language conventions. However, such a translation would be more transgressive of target-language of target-culture conventions. In the context of Cuban literature, it is worth considering whether the transfer of content, with all the concessions that would have to be made as to formal features in order to make it accessible to as wide an audience as that reached by exile Cuban literati, would be viable without the provision of extensive paratextual and co-textual information. It seems that what von Humboldt (Wilss 1982: 35) presented as an "impossible task" for the translator (i.e., finding the medium between staying "too close to the original, at the cost of taste and language of his nation" and adhering "too closely to the characteristics peculiar to his nation, at the cost of the original”) in 1796 still remains a "stumbling block" over two centuries later.

\section{ACKNOWLEDGMENTS}

The research that was conducted for the writing of this paper would not have been possible without a grant from the Carnegie Trust, for which I am extremely grateful. Thanks are also due to Par Kumaraswami, who was an inspiration for this project. I would also like to acknowledge the following people, who very generously gave of their time and provided their support: José Quesada Pantoja (Publishing Editor, Pueblo y Educación), a veritable source of information on all manner of issues; Victor Malagón (Chief Specialist, Arte y Cultura), who provided me with very useful insights into publishing policy in Cuba; and Daniel García (Director, Instituto Cubano del Libro), with whom I discussed the selection of authors for a publishing project and who gave me three anthologies and one contemporary collection of Cuban short stories, so that I could have an overview of the types of narrative that are deemed worthy of publication in Cuba. At the Instituto de Literatura y Lingüistica, I met with Gisela Cárdenas Molina (the President of 
the Asociación de Lingüistas de Cuba and the Secretary of the Academia Cubana de la Lengua) and its Chief Researcher in Cuban Literature, Emmanuel Tornés (writer, literary critic and university professor), both of whom shared anecdotes with me and proved to be an invaluable source of information about Cuban literature. I am also forever indebted to the staff of the Faculty of Foreign Languages (FLEX) at the University of Havana, especially Pedro Aragonés, Ida María Ayala, Roberto Espí, Xiomara García and Hilda Torres (in alphabetical order), who provided me with coffee, snacks and other essentials, and whose kindness and generosity I could not ever repay.

\section{NOTES}

1. Translated contributions by some of these authors were included in a collection edited by Mary G. Berg, Pamela Carmell and Anne Fountain, Cuba on the Edge: Short Stories from the Island (Critical, Cultural and Communications Press: Nottingham, 2007), whose purpose is to provide "glimpses of Cuba in 2007," rather than to present a diachronic trajectory of testimonial narratives.

2. The issue of censorship and how it impacts on the selection of works for publication, as well as that of the differences in literary production and editorial policy that exist between Havana and the provinces are noteworthy and merit separate, in-depth study.

3. The work of Cuban translators working in Cuba, however, achieves limited distribution in other Spanish-speaking countries. For an overview, see Curbelo (2004).

4. For instance, during the Special Period in the 1990s, the scarcity of paper severely affected the Cuban publishing industry.

5. Meschonnic famously introduced the notion of décentrement to the discipline in Pour la Poétique II (Meschonnic 1973). Since then, it has been applied by numerous translation scholars, such as Tymoczko (2007).

6. Although there have been many taxonomies of culture-specific terms in relation to translation, one of the most widely used references in current theory is Leppihalme's complex and comprehensive classification of realia (see, e.g., Leppihalme 1997; 2001).

7. As mentioned above, the same could be said of speakers of the source language who are members of a different cultural community.

8. Venuti's contribution lies in politicizing a discourse that is centuries old. Assimilation of the source text to the target culture is nothing new: it can be traced back to the Romans, and their translations of the Greek classics. It is worth nothing that this assimilation, which is perceived as an act of imperialistic appropriation by some scholars, could be seen as subversive in certain cases, such as in Ælfric's translation of the Lives of the Saints, in the Middle Ages, where he defied conventions and the established order of things (see Robinson 1998: 108): Ælfric followed a target-audience oriented approach when rendering the original text, which made it easier to apprehend, and, in doing so, he departed from the traditional, accepted, approach, which prescribed closeness to the "original text."

9. Several prominent figures within this field (such as Barbara Goddard) have written about the implications of gender politics in translation. As Chamberlain (1998: 96) states, quoting Maier (1985: 4), "Feminist translators have [...] advocated a translation of resistance that gives voice to the antagonist works but also 'speak[s] with them and place[s] them in a larger context."”

10. "If I asked for a bird in flight, a bird in flight [I would get]."

11. "He who has no Congolese [in him] has Calabar [in him]."

12. "The illumination of the sun started in the portion of the pavement that could be seen in front of the fence's gate, as if the border between light and shadow were drawn right there."

13. "Galardonado con el Premio de la Crítica en 1984, los textos reunidos en este libro narran el proceso de decadencia de la pequeña burguesía, específicamente de aquel sector que decidió enclaustrarse en sus espacios vitales como respuesta a las profundas transformaciones de la infraestructura política y socioeconómica que trajo consigo la Revolución." This translation and those below are mine.

14. "a white girl should be treated with the utmost care."

15. "carácter universal de los problemas humanos" (Tornés 2008)

16. "para comprender lo que pasa en Cuba, hay que vivir en Cuba" (Quesada Pantoja 2008)

17. "haber sido partícipe de todas esas situaciones" (Quesada Pantoja 2008)

18. "que no se viera realmente lo que está pasando" (Quesada Pantoja 2008) 
19. “sintaxis mental” (Quesada Pantoja 2008)

20. “un buen lector” (Quesada Pantoja 2008)

21. "el traductor tiene que ser alguien que traslade [emphasis added] la esencia del cuento, la atmósfera del cuento"

22. "el sabor de lo cubano" (Quesada Pantoja 2008)

23. "El contenido es la piel, pero lo más importante en la traducción es el alma, es el sistema nervioso" (Quesada Pantoja 2008)

24. “acercarse a Cuba” (Quesada Pantoja 2008)

25. "las experiencias que se relatan y la forma en que se cuenta" (Quesada Pantoja 2008)

26. "nuevas formas de decir. [...] Eso pasa en todos los países del mundo" (Quesada Pantoja 2008)

27. "las contradicciones entre las generaciones nuevas y las anteriores están en la forma pensar, en la forma de ver la vida, en la forma de enfrentar los problemas” (Quesada Pantoja 2008)

28. "la pérdida de la inocencia" (Tornés 2008)

29. "la recuperación de los que merecen ser recuperados" (Tornés 2008)

30. "la ahogaban" (Tornés 2008)

31. "un cambio muy significativo" (García 2008)

32. "normalmente, los que se publican en otros idiomas son los disidentes, las personas que no viven en Cuba, la diáspora” (Quesada Pantoja 2008)

33. "parten de una realidad que no es la misma" (García 2008)

34. "sentido de la cubanidad" (García 2008)

35. "no necesariamente, porque son cubanos [...] la mirada siempre la tienen hacia Cuba” (Tornés 2008)

36. “están rodeados de una información muy amplia" (Tornés 2008)

37. “más en sincronía con las preferencias de lectura internacional” (Tornés 2008)

38. “tienen ciertas improntas internacionales” (Tornés 2008)

39. "razones extraliterarias" (Tornés 2008)

40. "hay mucha propaganda y mucho dinero detrás de hablar de la Revolución Cubana desde fuera" (Quesada Pantoja 2008)

41. "lo difícil es hablar de lo que pasa en Cuba estando dentro" (Quesada Pantoja 2008)

42. Quesada Pantoja alluded to the fact that a single publishing house deals with the translation of all foreign works. An additional constraint is that authors often have to relinquish the copyright of their texts for them to be translated and published by Cuban publishing houses.

43. This is, of course, a necessarily subjective appraisal.

44. “valor spiritual” Malagón (2008)

45. "lo que se conoce es la literatura universal [...] textos canónicos" (Quesada Pantoja 2008)

46. “cuesta mucho a las personas empezar en el ámbito editorial” (Quesada Pantoja 2008)

47. “autocensura en las editoriales" (Quesada Pantoja 2008)

48. "se pueden malinterpretar ideas" (Quesada Pantoja 2008)

49. "que la gente entienda de otra manera lo que se publica" (Quesada Pantoja 2008)

50. Additionally, the wider distribution of Cuban testimonial narrative is also perceived as being important in the Spanish-speaking world.

51. "comprometer a Cuba con esos escritores para que puedan ser conocidos" (Quesada Pantoja 2008)

52. “no son autores de corte barroco" (Tornés 2008)

53. “economía del lenguaje” (Tornés 2008)

54. “los más relacionados con los problemas normales de la cotidianeidad de Cuba” (Quesada Pantoja 2008)

55. “para llevarlos a otro lugar” (Quesada Pantoja 2008)

56. “notas, aclaraciones al lector, un glosario de términos” (Quesada Pantoja 2008)

\section{REFERENCES}

Bassnett, Suzanne and Lefevere, André (1992): General Editor's Preface. In: André Lefevere, ed. Translation, Rewriting and the Manipulation of the Literary Fame. London: Routledge, vii-viii.

Benjamin, Walter (1923/1992): The Task of the Translator. In: Illuminations. (Translated by Harry ZoHn) London: Fontana Press.

Berman, Antoine (1992): The Experience of the Foreign. Culture and Translation in Romantic Germany. (Translated by Stefan Heyvaert) Albany: State University of New York Press. 
BhabHa, Homi K., ed. (1990): Nation and Narration. London/New York: Routledge.

BнавнA, Homi K. (1994): The Location of Culture. London/New York: Routledge.

Cardentey Levin, Antonio (2009): El imaginario doméstico en Casas del Vedado de María Elena Llana. Especulo. Revista de estudios literarios. 42. Visited on 15 October 2010, <http:// www.ucm.es/info/especulo/numero42/mellana.html>.

Chamberlain, Lori (1998): Gender metaphorics in translation. In: Mona Baker, ed. Encyclopedia of Translation Studies. London/New York: Routledge, 93-96.

Curbelo, Jesús David (2004): Para una historia de la traducción en Cuba. HISTAL. Visited on 10 October 2010, <http://www.histal.ca/wp-content/uploads/2011/08/Para-una-historia-dela-traducci\%C3\%B3n-en-Cuba.pdf $>$.

Derrida, Jacques (1981): Positions. (Translated by Alan Bass) London: The Athlone Press.

Evans, Ruth (1998): Metaphors of Translation. In: Mona BAKeR, ed. Encyclopedia of Translation Studies. London/New York: Routledge, 149-153.

Even-Zohar, Itamar (1979): Polysystem Theory. Poetics Today. 1(1-2):287-310.

Hatim, Basil and Mason, Ian (1990): Discourse and the Translator. London: Longman.

Hoffmann, Bert and Whitehead, Laurence, eds. (2007): Debating Cuban Exceptionalism. Basingstoke: Palgrave Macmillan.

KAPCiA, Antoni (2008): Does Cuba fit yet or is it still 'Exceptional.' Journal of Latin American Studies. 40(4):627-650.

Leppinalme, Ritva (1997): Culture Bumps. An Empirical Approach to the Translation of Allusions. Clevedon: Multilingual Matters.

Leppihalme, Ritva (2001): Translation strategies for realia. In: Pirjo Kukkonen and Ritva Hartama-Heinonen, eds. Mission, Vision, Strategies and Values. A Celebration of Translator Training and Translation Studies in Kouvola. Helsinki: Helsinki University Press, 139-148.

Llana, María Elena (1983/2003): Un abanico chino. In: Salvador Bueno and Andrés BansarT, eds. Cuentos negristas. Caracas: Biblioteca Ayacucho.

Meschonnic, Henri (1973): Pour la Poétique II: Epistémologie de l'écriture, Poétique de la traduction. Paris: Gallimard.

Niranjana, Tejasinini (1992): Siting Translation. History, Poststructuralism and the Colonial Context. Berkeley: University of California Press.

Robinson, Douglas (1998): Ideology and Translation. In: Mona BAKer, ed. Encyclopedia of Translation Studies. London/New York: Routledge, 106-112.

Simon, Sherry (1996): Gender in Translation. London/New York: Routledge.

Toury, Gideon (1980): In Search of a Theory of Translation. Tel-Aviv: Porter Institute for Poetics and Semiotics.

Toury, Gideon (1995): Descriptive Translation Studies and Beyond. Amsterdam/Philadelphia: Benjamins.

Түмосzко, Maria (2007): Enlarging Translation, Empowering Translators. Manchester: St. Jerome. Venuti, Lawrence (1995): The Translator's Invisibility. London: Routledge.

WiLss, Wolfram (1982): The Science of Translation. Problems and Methods. Tübingen: Gunter Narr Verlag.

YÁÑez, Mirta (1976/2003): Todos los negros tomamos café. In: Salvador Bueno and Andrés BAnsart, eds. Cuentos negristas. Caracas: Biblioteca Ayacucho.

\section{INTERVIEWS}

Interview with Daniel García, Director of Instituto Cubano del Libro, on 2 April 2008.

Interview with Victor Malagón, Chief Specialist of Arte y Cultura, on 29 March 2008.

Interview with José Quesada Pantoja, Publishing Editor of Pueblo y Educación, on 27 March 2008.

Interview with Emmanuel ToRnés, Chief Researcher in Cuban Literatura at the Instituto de Literatura y Lingüística, on 28 March 2008. 